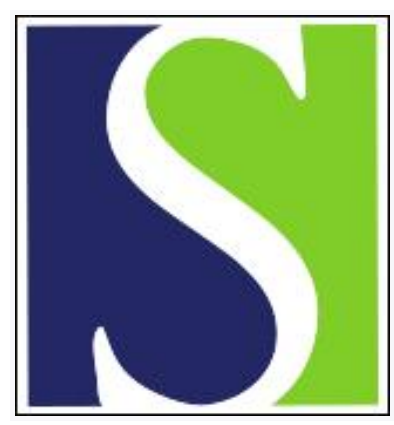

Scand J Work Environ Health 1996;22(5):364-368

https://doi.org/10.5271/sjweh.155

Issue date: Oct 1996

Prevalence of Helicobacter pylori infection among sewage workers

by Friis L, Engstrand L, Edling C

Key terms: epidemiology; immunoglobulin $\mathrm{G}$ antibody; occupational epidemiology; serology; waste water

This article in PubMed: www.ncbi.nlm.nih.gov/pubmed/8923610

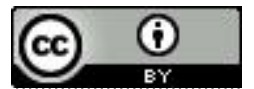




\title{
Prevalence of Helicobacter pylori infection among sewage workers
}

\author{
by Lennart Friis, MD,' Lars Engstrand, PhD, ${ }^{2}$ Christer Edling, $P h D^{1}$
}

\begin{abstract}
Friis L, Engstrand L, Edling C. Prevalence of Helicobacter pylori infection among sewage workers. Scand J Work Environ Health $1996 ; 22: 364-8$.
\end{abstract}

\begin{abstract}
Objectives An increased risk for gastric cancer among sewage workers has been described in several studies. During the last decade the bacterium Helicobacter pylori has emerged as one important risk factor for gastric cancer and is now considered a class I carcinogen by the International Agency for Research on Cancer. The route of transmission for this bacterium remains unclear, but fecal-oral transmission has been proposed. If true, this might entail a yet undescribed risk for sewage workers.

Method The prevalence of immunoglobulin G (IgG) antibodies against $H$ pylori was studied with a crosssectional study design in a group of 289 municipal workers. Samples of serum from 151 sewage workers at 11 sewage plants in Sweden and of serum from 138 referents were analyzed. The referents were group matched for age and socioeconomic status.

Results The prevalence of $\operatorname{IgG}$ antibodies against $H$ pylori among sewage workers did not differ from that of the referents. The adjusted odds ratio (adjOR) was calculated from a logistic model with age and residence as confounding variables (adjOR $0.90,95 \%$ confidence interval $0.53-1.5$ ). The previously described increase in the prevalence of $\mathrm{IgG}$ antibodies against $H$ pylori with increasing age was observed. Geographic differences were also observed in the prevalence of $H$ pylori in Sweden.

Conclusions The exposures in sewage work in Sweden do not cause an increased risk of infection with H pylori.
\end{abstract}

Key terms epidemiology, immunoglobulin $\mathrm{G}$ antibodies, occupational, serology, waste water.

There are many examples of pathogens spread by human excreta through sewage water. Polio viruses have been both isolated and detected by polymerase chain reaction (PCR) from sewage water (1). Clark et al (2) reviewed early reports about risks for infectious diseases among sewage workers. Skinhøj reported an increased occurrence of antibodies against hepatitis A virus in Danish sewage-exposed workers (3). Heng et al (4) described an increased risk for hepatitis A infection among sewage workers in Singapore.

In 1982 Helicobacter pylori was first isolated in humans (5), but the route of transmission still remains unclear (6). The bacterium has been isolated from human feces by Thomas et al (7) and Kelly et al (8), while other groups have reported failures (9). If there is fecal dissemination, an exposure for $H$ pylori is conceivable among sewage workers.

The risk for $H$ pylori infection has been described in other occupational settings. Nurses were at increased risk $(10)$, but dental workers were not $(11,12)$. In one study of gastroenterologists an increased risk for infection with $H$ pylori was reported (13), while another study found no increased risk (14). Although not conclusive, these studies indicate that some occupational exposures may cause infection with $H$ pylori.

$H$ pylori has been associated with several types of gastric disease, for example, chronic gastritis (15), atrophic gastritis (16), and peptic ulcers $(17,18)$. $H$ pylori is also associated with an increased risk for cancer of the stomach (19), and recently the International Agency for Research on Cancer (IARC) classified $H$ pylori as a human class I carcinogen (20). Several epidemiologic studies have described increased risks for various cancers among sewage workers, among them cancer of the stomach $(21-23)$. An analysis of the Cancer-Environment Register of Sweden for the incidence of stomach cancer by industry and occupation showed a significantly increased risk for stomach cancer in workers em-

1 Department of Occupational and Environmental Medicine, University Hospital, Uppsala, Sweden.

2 Department of Clinical Microbiology, University Hospital, Uppsala, Sweden.

Reprint requests to: Dr Lennart Friis, Department of Occupational and Environmental Medicine, University Hospital, S-751 85 Uppsala, Sweden (e-mail: Lennart.Friis@arbmed.uas.se). 
ployed among waterworks (24). These workers are often engaged at both municipal drinking water plants and sewage plants.

The evidence of an increased incidence of gastric cancers among sewage workers formed the impetus for this study of possible expostre for $H$ pylori among sewage workers. The hypothesis tested is whether sewage workers are at risk to be infected by $H$ pylori in their work.

\section{Subjects and methods}

The prevalence of immunization against $H$ pylori was determined in a group of Swedish sewage workers. The study design was cross-sectional. All 156 workers employed at the municipal plants treating waste water or sludge in 11 municipalities in mid-Sweden were invited to participate, and 151 (97\%) did so. The referents were selected from laborers from the same, or closely situated, local authorities. The result was a group matched for geographic location. They were also group matched for the two well-established confounding factors regarding $H$ pylori infection, age ( \pm 5 years) and socioeconomic status (25). Gender has not been reported to be important in this context. One hudred and forty-seven referents meeting these criteria were found, and $138(94 \%)$ participated. The mean age was 46.5 (SD 9.95) years for the participating sewage workers and 45.4 (SD 10.4) years for the participating referents. Nine of the participating sewage workers and one of the referents were women.

Data about current and previous jobs reflecting exposure to sewage were collected through a questionnaire to each participant in the study.

A blood sample for the serum analysis was collected from each worker by routine venipuncture. After centrifugation the serum samples were kept at $-18^{\circ} \mathrm{C}$ and analyzed in batches. Sera were examined for immunoglobulin $\mathrm{G}(\operatorname{IgG})$ antibodies using the HM CAPTM immunoassay (Enteric Products Inc, New York, United States), according to the instructions of the manufacturer. The sensitivity and specificity of this assay ranged from $94 \%$ to $98 \%$ (26) and from $92 \%$ to $97 \%$ (27), respectively. In a few cases with borderline results the sera were reanalyzed using a commercial immunoblot technique (Genelabs Diagnostics, Singapore).

The project was discussed with, and supported by, the employer and the local union at each place. In carrying through the project we also had assistance from several local occupational health care units.

Statistical analyses with $2 \times 2$ table statistics and logistic regression were performed using the computer programs Epi Info (Centers for Disease Control, Atlanta, Georgia, United States and World Health Organization, Geneva, Switzerland), and SPIDA (The Statistical Laboratory, Macquarie University, Australia). Relative risks with $95 \%$ confidence intervals $(95 \% \mathrm{CI})$ were calculated in the $2 \times 2$ table analyses. Odds ratios (OR) and adjusted odds ratios (adjOR) with 95\% confidence intervals were calculated from the logistic regression models. The near collinearity diagnostics for the logistic regression analysis in SPIDA, using condition numbers and variance decomposition proportions, was applied.

\section{Results}

In the crude $2 \times 2$ table analysis there was no increase in the relative risk for seropositivity for $H$ pylori among the sewage workers when they were compared with the referents (table 1). Neither was there any difference between the sewage workers and the referents in an agestratified analysis (table 2). However, the previously re-

Table 1. Occurrence of immunoglobulin $G$ antibodies to Helicobacter pylori in a group of 151 Swedish sewage workers compared with that of 138 referents not occupied in sewage work (relative risk $=0.98,95 \%$ confidence interval $0.68-1.5$ ).

\begin{tabular}{lcc}
\hline Group & $\begin{array}{c}\text { Seropositive } \\
\text { subjects (N) }\end{array}$ & $\begin{array}{c}\text { Seronegative } \\
\text { subjects (N) }\end{array}$ \\
\hline Sewage workers & 43 & 108 \\
Referents & 40 & 98 \\
\hline
\end{tabular}

Seropositive $=$ antibodies against $H$ pylori in serum

b Seronegative $=$ no antibodies against $H$ pylori in serum.

Table 2. Prevalence of immunoglobulin $\mathrm{G}(\mathrm{lg} \mathrm{G})$ antibodies to Helocobacter pylori in three age groups of Swedish sewage workers compared with their referents.

\begin{tabular}{|c|c|c|c|c|c|c|c|c|c|}
\hline \multirow[t]{3}{*}{ Group } & \multicolumn{9}{|c|}{ Age } \\
\hline & \multicolumn{3}{|c|}{$<31$ years } & \multicolumn{3}{|c|}{$31-50$ years } & \multicolumn{3}{|c|}{$>50$ years } \\
\hline & $\begin{array}{l}\text { Sero- } \\
\text { positive } \\
\text { subjects } \\
\text { (N) }\end{array}$ & $\begin{array}{c}\text { Sero- } \\
\text { negative } \\
\text { subjects } \\
(\mathrm{N})\end{array}$ & $\begin{array}{c}\text { Prevalence } \\
\text { of IgG } \\
\text { antibodies }\end{array}$ & $\begin{array}{l}\text { Sero- } \\
\text { positive } \\
\text { subjects } \\
\text { (N) }\end{array}$ & $\begin{array}{c}\text { Sero- } \\
\text { negative } \\
\text { subjects } \\
\text { (N) }\end{array}$ & $\begin{array}{c}\text { Prevalence } \\
\text { of lgG } \\
\text { antibodies }\end{array}$ & $\begin{array}{l}\text { Sero- } \\
\text { positive } \\
\text { subjects } \\
\text { (N) }\end{array}$ & $\begin{array}{l}\text { Sero- } \\
\text { negative } \\
\text { subjects } \\
\text { (N) }\end{array}$ & $\begin{array}{c}\text { Prevalence } \\
\text { of IgG } \\
\text { antibodies }\end{array}$ \\
\hline $\begin{array}{l}\text { Sewage workers } \\
\text { Referents }\end{array}$ & $\frac{-}{1}$ & $\begin{array}{l}11 \\
13\end{array}$ & $\begin{array}{l}0 \\
0.07\end{array}$ & $\begin{array}{l}18 \\
17\end{array}$ & $\begin{array}{l}64 \\
57\end{array}$ & $\begin{array}{l}0.22 \\
0.23\end{array}$ & $\begin{array}{l}25 \\
22\end{array}$ & $\begin{array}{l}33 \\
28\end{array}$ & $\begin{array}{l}0.43 \\
0.44\end{array}$ \\
\hline
\end{tabular}


ported increasing prevalence with age was seen in this analysis.

Logistic regression analyses were performed to control for possible confounding. The dichotomous dependent variable in the logistic regression analyses was immunization against $H$ pylori. The exposure was described in the modeling by a dichotomous variable for present employment at a sewage plant ("sewage worker"). Three alternative exposure variables were also tried, but the results did not change. These alternative variables were the two dichotomous variables "ever had occupational sewage exposure" and "any exposure to sewage in the current job" and the continuous variable "years in sewage work." The known confounder age was included as a confounder variable. Due to small numbers in some municipalities four geographic strata were used to control for possible confounding by geography: Gävle, Tierp, and Enköping in the southeast (region 1); the largest city in the study, Uppsala (region 2); Säter and Smedjebacken in southern Dalarna (region 3); and Älvdalen, Orsa, Mora, and Rättvik in northern Dalarna (region 4).

In crude analyses, with logistic regression models with a single independent variable, neither of the four alternative exposure variables showed an increased risk for the sewage workers (table 3). However, there were statistically significant increased odd ratios (OR) for the confounders age and geographic region. Although not completely consistent, one difference between the geographic regions was the proportion of rural population in the different municipalities. Thus this socioeconomic variable was also included in the analyses.

A logistic model with the exposure variable "sewage worker" and the confounders age and geographic regions indicated no increase in the risk for immunization against $H$ pylori among the sewage workers. The adjOR was

Table 3. Odds ratios (OR) and $95 \%$ confidence intervals ( $95 \% \mathrm{Cl}$ ) calculated from crude logistic regression analyses (univariable models) for the presence of immunoglobulin $G(\lg G$ ) antibodies to Helicobacter pylori among sewage workers and their referents.

\begin{tabular}{|c|c|c|}
\hline & OR & $95 \% \mathrm{Cl}$ \\
\hline Sewage worker & 0.99 & $0.60-1.6$ \\
\hline Years in sewage work & 1.0 & $0.98-1.0$ \\
\hline $\begin{array}{l}\text { Ever had occupational sewage } \\
\text { exposure }\end{array}$ & 1.0 & $0.57-1.8$ \\
\hline $\begin{array}{l}\text { Any exposure for sewage in } \\
\text { present job }\end{array}$ & 1.1 & $0.68-1.9$ \\
\hline \multicolumn{3}{|l|}{ Geographic dummy variables } \\
\hline $\begin{array}{l}\text { Region } 1 \\
\text { Region } 2 \\
\text { Region } 3 \\
\text { Region } 4\end{array}$ & $\begin{array}{l}1 \\
1.2 \\
0.92 \\
2.1\end{array}$ & $\begin{array}{c}0.60-2.6 \\
0.40-2.1 \\
1.1-4.1\end{array}$ \\
\hline $\begin{array}{l}\text { Rural population in the } \\
\text { municipality (per thousand) }\end{array}$ & 1.2 & $0.99-1.6$ \\
\hline Age (years/10) & 1.8 & $1.4-2.4$ \\
\hline Gender $($ male $=1$, female $=0)$ & 3.7 & $0.47-30$ \\
\hline
\end{tabular}

0.90 (95\% CI $0.53-1.5)$. This analysis also showed an age dependence and regional differences with the same pattern and magnitudes in risk estimates as the crude analyses. Using the proportion of the rural population in the model instead of the geographic regions resulted in risk estimates close to those determined with the crude analyses.

\section{Discussion}

This study showed no increased risk for infection with $H$ pylori among sewage workers. Consequently it does not support the hypothesis that $H$ pylori infection is a cause of the increased risk of gastric cancer among sewage workers.

The Eurogast study group (28) reported a sixfold increase in the risk for gastric cancer in a $H$ pyloriinfected population, when compared with an uninfected population. In a background population with $30 \%$ seropositivity for $H$ pylori, almost all the sewage-exposed persons should have been seropositive, if $H$ pylori infection alone was to explain the doubled risk for gastric cancer. The relative risk for gastric cancer among the sewage-exposed workers has been reported to be approximately 2 to $2.5(21,22)$.

The number of nonparticipants among the exposed and referents was small and, therefore, was not expected to affect the validity of the study. In view of the studied effect variable, not giving any symptoms in most cases, a differential selection of individuals is not likely. Misclassification of exposure could conceal a possible overrisk. All the participating individuals completed the questionnaire about job tasks. Some presently unexposed persons were found to have had previous exposure to waste water or sewage sludge. Due to the chronic, if not next to lifelong, nature of the $H$ pylori infection, these persons were treated as exposed in one separate analysis. There were also some workers not employed at sewage plants, for example, construction workers repairing pipes, who were occasionally exposed to sewage water in their jobs. These men were also considered exposed in another separate analysis. The alternative analyses did not change the conclusions about waste water or sewage sludge as a risk factor for $H$ pylori infection.

It is not likely that there was any reduction in the studied prevalence due to healthy worker selection. The referents were also active workers with a comparable degree of manual work. Furthermore, the dependent variable in our study, prevalence of $\operatorname{IgG}$ antibodies against $H$ pylori, is related to morbidity for very few of the affected.

The referents were group-matched for age, socioeconomic status, and geography to reduce the risks bias. 
These possible confounders should have minimal effect on the study results. Therefore, our finding of an increased risk for infection with $H$ pylori in the northwestern region does not affect our conclusion about no observed risk in relation to sewage exposure. This previously not described geographic difference in Sweden cannot be explained by our study.

One might suspect that the frequent use of antibiotics could eradicate $H$ pylori and thus account for reduced prevalence of antibodies against this bacterium. However, the presence of specific antibodies does not protect against the recurrence of infection after temporary clearance (29). Furthermore, monotherapy of the $H$ pylori infection with a single antibiotic does not effectively eradicate the organism (30). Recently one Canadian study also showed that antibiotics taken in the preceding year had no effect on $H$ pylori prevalence (31).

The previously observed increased risk for gastric cancer among sewage-exposed workers in Sweden is not based on today's exposures. The induction-latency period for cancers is normally decades, and the possible causes of this observed overrisk should be searched for at least 20 to 30 years earlier in time. The virulence of $H$ pylori may be too low to facilitate an infection at present exposure levels. If the observed increase in prevalence with increasing age in the population is a cohort effect, one would also expect that the potential exposure for $H$ pylori through waste water may have been higher among the sewage workers some decades ago. However, the age-stratified analysis done in this study does not indicate an increased risk for $H$ pylori infection among the oldest sewage workers when compared with their agematched referents.

In a recent study on $H$ pylori infection and foreign travel, it was found that none of 133 young adult Swedish seronegative travelers seroconverted after episodes of gastroenteritis in developing countries (32). Since gastroenteritis is a marker of exposure to fecally contaminated food or water, this possible $H$ pylori challenge did not change the infection rate. $H$ pylori is probably acquired at a young age especially in developing countries $(33,34)$. It may be that adults are protected against the infection due to a more competent immune defense system.

The present exposures in sewage work in Sweden do not cause an increased risk for infection with $H$ pylori. Consequently, it is not probable that the previously observed increased risk for gastric cancer among Swedish sewage workers is explained by $H$ pylori infection. Other factors influencing the risk for gastric cancer, such as dietary factors, smoking habits, and other occupational exposures, must be considered in future studies of this tumor among sewage workers $(35,36)$. Although this study indicates that a possible presence of these bacteria in waste water is of no significance for the health of sewage workers, sewage-contaminated drinking water may still constitute a public health risk. Therefore, further studies of the possible spreading of $H$ pylori through waste water may be warranted, especially in areas with a high prevalence of the infection.

\section{Acknowledgments}

We wish to express our gratitude to the many people in the municipal authorities and occupational health care units who helped us with the planning and accomplishment of this study. The skillful assistance of Ms Ulla Zettersten and Ms Åsa Lundin is gratefully acknowledged.

This work was supported by grants from the Swedish Medical Research Council (projects no 10617 and 10848), the Ake Wiberg Foundation and the Lions Cancer Society at the Uppsala University Hospital.

\section{References}

1. Tambini G, Andrus JK, Niarques E, Boshell J, Pallansch M, de Quadros CA, et al. Direct detection of wild poliovirus circulation by stool surveys of healthy children and analysis of community wastewater. J Infect Dis 1993;168:1.510 - 4.

2. Clark CS, Cleary EJ, Schiff GM, Linnemann CC, Phair JP, Briggs TM. Disease risks of occupational exposure to sewage. J Environ Eng Div (Am Soc Civil Eng) 1976;102: 375-88.

3. Skinhøj P, Hollinger FB, Hovind-Hougen K, Lous P. Infectious liver diseases in three groups of Copenhagen workers: correlation of Hepatitis A infection to sewage exposure. Arch Environ Health 1980;36:139_-43.

4. Heng B, Goh KT, Doraisingham S, Quek GH. Prevalence of hepatitis A virus infection among sewage workers in Singapore. Epidemiol Infect 1994;113:121—8.

5. Warren JR, Marshall B. Unidentified curved bacilli on gastric epithelium in active chronic gastritis. Lancet 1983;1:1273-5.

6. Goodman KJ, Correa P. The transmission of Helicobacter pylori: a critical review of the evidence. Int J Epidemiol 1995; $24: 875-87$.

7. Thomas JE, Gibson GR, Darboe MK, Dale A, Weaver LT. Isolation of Helicobacter pylori from human faeces. Lancet 1992;320:1194-5.

8. Kelly SM, Pitcher MCL, Farmery SM, Gibson GR. Isolation of Helicobacter pylori from feces of patients with dyspepsia in the United Kingdom. Gastroenterology 1994;107:1671—4.

9. Sahay P, West AP, Hawkey PM, Axon ATR. Isolation of Helicobacter pylori from faeces. J Infect 1995;30:262-3.

10. Wilhoite SL, Ferguson DA Jr, Soike DR, Kalbfleisch JH, Thomas E. Increased prevalence of Helicobacter pylori antibodies among nurses. Arch Intern Med 1993;53:708-12.

11. Malaty HM, Evans DJ, Abramovitch K, Evans DG, Graham DY. Helicobacter pylori infection in dental workers: a seroepidemiology study. Am J Gastroenterol 1992;87:1728—31.

12. Banatvala N, Abdi Y, Clements L, Herbert A-M, Davies J, Bagg J, et al. Helicobacter pylori infection in dentists - a case-control study. Scand J Infect Dis 1995;27:149—51. 
13. Mitchell HM, Lee A, Carrick J. Increased incidence of Campylobacter pylori infection in gastroenerologists: further evidence to support person-to-person transmission of $\mathrm{C}$ pylori. Scand J Gastroenterol 1989;29:396-400.

14. Pristautz H, Eherer A, Breizinschek R, Truschnig-Wilders M, Petritsch W, Schreiber F, et al. Prevalence of Helicobacter pylori antibodies in the serum of gastroenterologists in Austria. Endoscopy 1994;26:690-6.

15. Rauws EAJ, Langenberg W, Houthoff HJ, Zanen HC, Tytgat GNJ. Campylobacter pyloridis-associated chronic active antral gastritis. Gastroenterology 1988;94:33-40.

16. Karnes WE, Samloff IM, Siurala M, Kekki M, Sipponen P, Kim SWR, et al. Positive serum antibody and negative tissue staining for Helicobacter pylori in subjects with atrophic body gastritis. Gastroenterology 1991;101:167-74.

17. Coghlan JG, Humphries H, Dooley C, Keane C, Gilligan D, McKenna D, et al. Canpylobacter pylori and recurrence of duodenal ulcers - a 12-month follow-up study. Lancet 1987; 2:1109-11.

18. Rauws EAJ, Tytgat GNJ. Cure of duodenal ulcer associated with eradication of Helicobacter pylori. Lancet 1990;335: $1233-5$.

19. Hansson LE, Engstrand L, Nyrén O, Evans DJ Jr, Lindgren A, Bergström R, et al. Helicobacter pylori infection: independent risk indicator of gastric adenocarcinoma. Gastroenterology 1993;105:1098-103.

20. International Agency for Research on Cancer (IARC). Shistosomes, liver flukes, and Helicobacter pylori. Lyon: IARC, 1994. IARC monographs on the evaluation of carcinogenic risks to humans, vol 61.

21. Lafleur J, Vena JE. Retrospective cohort mortality study of cancer among sewage plant workers. Am J Ind Med 1991;19: $75-86$.

22. Friis L, Edling C, Hagmar L. Mortality and incidence of cancer among sewage workers: a retrospective cohort study. Br J Ind Med 1993;50:653-7.

23. Rapiti E Sperati A, Fano V, Dell'Orco V, Forastiere F. Mortality among municipal workers in garbage handling, waste incinerating and sewage treatment: a retrospective cohort study. Epidemiology 1995;6:\$135.

24. Chow W-H, McLaughlin JK, Malker HSR, Weiner JA, Ericsson JLE, Stone BJ, et al. Occupation and stomach cancer in a cohort of Swedish men. Am J Ind Med 1994;26:511-20.
25. Eurogast study group. Epidemiology of, and risk factors for, Helicobacter pylori infection among 3194 asymptomatic subjects in 17 populations. Gut 1993;34:1672-6.

26. Graham DY, Evans DG, Evans DJ. An accurate rapid and convenient physician-office serologic test for detection of $\mathrm{H}$. pylori infection. Am J Gastroenterol 1994;89:1305.

27. Marchildon P, Ciota L, Smith J, Zamaniyan F, Peacock J Evaluation of three commercial EIAs for detection of $\mathrm{H}$. pylori infection when compared to the $\mathrm{C} 13$ urea breath test. Am J Gastroenterol 1994;89:1341.

28. Eurogast study group. An international association between Helicobacter pylori infection and gastric cancer. Lancet 1993; $341: 1359-62$.

29. Langenberg W, Rauws EAJ, Widjojokusumo A, Tytgat GNJ, Rietra PJGM. Follow-up of individuals with untreated campylobacter pylori-associated gastritis and of non-infected persons with non-ulcer dyspepsia. J Infect Dis 1988;157:12458.

30. Veldhuyzen van Zanten SJO, Sherman PM. Indications for treatment of Helicobacter pylori infection: a systematic overview. Can Med Assoc J 1994;150:189—98.

31. Veldhuyzen van Zanten SJO, Pollak T, Best LM, Bezanson GS, Marrie T. Increasing prevalence of Helicobacter pylori infection with age: continuous risk of infection in adults rather than cohort effect. J Infect Dis 1994;169:434-7.

32. Lindkvist $P$, Wadström $T$, Giesecke $J$. Helicobacter pylori infection and foreign travel. J Infect Dis 1995;172:1135—6.

33. Graham DY, Adam E, Reddy GT, Agarwal JP, Agarwal R, Evans DJ Jr, et al. Seroepidemiology of Helicobacter pylori infection in India: comparison of developing and developed countries. Dig Dis Sci 1991;36:1084-8.

34. Blecker U, Hauser B, Lanciers S, Peeters S, Suys B, Vandenplas $Y$. The prevalence of Helicobacter pylori-positive serology in asymptomatic children. J Pediatr Gastroenterol Nutr $1993 ; 16: 252-6$

35. Hwang H, Dwyer J, Russel RM. Diet, Helicobacter pylori infection, food preservatives and gastric cancer risk: Are there new roles for preventive factors? Nutr Rev 1994;52:75-83.

36. Cocco P, Ward MH. Occupational exposures and gastric cancer aetiology. Eur J Gastr Hepatol 1994;6:1089—96.

Received for publication: 11 December 1995 